\title{
Effect of Integrated Nutrient Management on Productivity and Profitability of Maize
}

\author{
Shambhu Sharan Kumar*, Pradeep Prasad and Daleshwar Rajak
}

Agricultural Engineering, Zonal Research Station, Darisai BAU, Ranchi, Jharkhand, India

*Corresponding author

A B S T R A C T

Keywords

Productivity,

Profitability,

Net return, INM,

Growth, Yield

attributes and

economics.

Article Info

Accepted:

28 October 2017

Available Online:

10 December 2017
A field experiment was conducted during kharif season of 2014 and 2015 at Zonal Research Station, Darisai (East Singhbhum) under Birsa Agricultural University, Ranchi, Jharkhand. The experiment was designed in Randomized Block Design having 8 treatments viz. $\mathrm{T}_{1}-100 \% \mathrm{RDF}, \mathrm{T}_{2}-125 \% \mathrm{RDF}, \mathrm{T}_{3}-150 \% \mathrm{RDF}, \mathrm{T} 4-75 \% \mathrm{RDF}+$ Azotobacter $+\mathrm{PSB}, \mathrm{T}_{5}-\mathrm{RDF}+5$ tons $\mathrm{FYM} / \mathrm{ha}, \mathrm{T}_{6}-\mathrm{RDF}+2.5$ tons $\mathrm{FYM} / \mathrm{ha}, \mathrm{T}_{7}-$ Farmers practice and $\mathrm{T}_{8^{-}}$control and each replicated thrice. The RDF used was 120:60:40 NPK/ha. The seed rate, spacing and variety taken in the experiment was $20 \mathrm{~kg} / \mathrm{ha}, 60 \mathrm{~cm} \times 25 \mathrm{~cm}$ and HQPM-1 respectively. The pooled results revealed that treatment $\mathrm{T}_{3}(150 \% \mathrm{RDF})$ recorded significantly higher growth parameters and yield attributes viz. plant height $(201.90 \mathrm{~cm})$, number of grains/cob (393.20), test weight $(223.25 \mathrm{~g})$ and grain yield $\left(52.05 \mathrm{q} \mathrm{ha}^{-1}\right)$ which was closely followed by treatment $\mathrm{T}_{5}(\mathrm{RDF}+5$ tons $\mathrm{FYM} /$ ha and recorded plant height $(200.30 \mathrm{~cm})$, number of grains/cob (391.95), test weight $(223.15 \mathrm{~g})$ and grain yield (51.70 $\mathrm{q} \mathrm{ha}^{-1}$ ) and was found to be at par to treatment $\mathrm{T}_{3}$. The pooled table 2 shows that maximum net return and $\mathrm{BC}$ ratio was computed in treatment $\mathrm{T}_{3}$ having values as Rs.35914.00 and 1.41 respectively followed by treatment $\mathrm{T}_{5}$.

\section{Introduction}

Maize (Zea mays L.) is the third most important cereal crop next to wheat and rice belonging to family Poaceae. In India, it is cultivated in an area of $9.43 \mathrm{~m}$ ha with a production of $24.35 \mathrm{~m} \mathrm{t}$ and productivity of $2583 \mathrm{~kg} \mathrm{ha}^{-1}$ (GOI, 2012). It is used as a source of carbohydrate to humans and animals due to its high feeding value (Undie et al., 2012). Maize is used as food, feed and nowadays it is gaining tremendous importance on account of its potential uses in manufacturing starch, rayon, adhesives, resins, dye, boot polish etc. and due to this it is rightly called "miracle crop" and also known as "queen of cereals". Intensive cultivation, use of unbalanced and inadequate fertilizers accompanied by restricted use of manures have made the soils not only deficient in the nutrients but also deteriorated soil health resulting in decline in crop response to recommended dose of fertilizers. Thus, Integrated Nutrient Management (INM) has assumed a great importance and has vital significance in maintaining soil productivity. Organic manures viz. FYM, vermicompost etc. not only supply macronutrients, meet the requirements of micronutrients, improve soil health and also increases water holding capacity of the soils. The organic fertilizers in addition to nutrients contain microbial load 
and growth promoting substances which help in boosting plant growth, metabolic activity and resistance to pest and diseases. Boosting yield, reducing cost of production and improving soil health are three interlinked components of sustainable triangle (Singh et al., 2016). Before green revolution era organic manures were the primary source of nutrients for crop production. In recent years there has been renewed interest in use of FYM which is attributed to concerns for maximizing sustainable agricultural production besides preserving the environment. Fertilizers are able to increase crop yields additionally produce enough residues for soil fertility management, while organic sources rehabilitate less responsive soils and makes them responsive to fertilizers (Vanlauwe et al., 2010). In INM, all the possible source of plant nutrients are applied based on economic consideration and the balance required for the crop is supplemented with chemical fertilizers. The INM approach not only enhances production and profitability of crop like maize but also aids in maintaining the permanent fertility status of the soil.

With this background, the present investigation entitled "Effect of Integrated Nutrient Management on productivity and profitability in maize (Zea mays L.)" was designed and conducted during kharif season of 2014 and 2015 at Zonal Research Station, Darisai, under Birsa Agricultural University, Ranchi, Jharkhand with the aim to assess the response of INM on productivity and profitability of maize in this region.

\section{Materials and Methods}

An experiment was conducted during kharif season of 2014 and 2015 at Zonal research Station, Darisai, East Singhbhum under Birsa Agricultural University, Ranchi, Jharkhand, for sub-agro climatic zone-VI, which comes under South Eastern plateau and situated at $22^{\circ} 41^{\prime}$ North latitude, $86^{\circ} 23^{\prime}$ East longitude and at an altitude of $521 \mathrm{~m}$ above mean sea level. The zone is characterized by humid to sub- tropical type of climate. The annual rainfall varies between $1200-1500 \mathrm{~mm}$. The soil was sandy loam in texture with $\mathrm{p}^{\mathrm{H}}$ 5.6. The experimental field soil was low in organic carbon, nitrogen and phosphorus but medium in potash. The experiment was designed in Randomized Block Design having 8 treatments viz. $\mathrm{T}_{1}-100 \%$ RDF, $\mathrm{T}_{2}-125 \%$ $\mathrm{RDF}, \mathrm{T}_{3}-150 \%$ RDF, $\mathrm{T}_{4}-75 \% \quad \mathrm{RDF}+$ Azotobacter + PSB, $\mathrm{T}_{5}-\mathrm{RDF}+5$ tons FYM/ha, $\mathrm{T}_{6^{-}} \mathrm{RDF}+2.5$ tons $\mathrm{FYM} / \mathrm{ha}, \mathrm{T}_{7^{-}}$ Farmers practice and $\mathrm{T}_{8^{-}}$control and each replicated thrice. The RDF used was 120:60:40 NPK/ha. The seed rate, spacing and variety taken in the experiment was 20 $\mathrm{kg} / \mathrm{ha}, \quad 60 \mathrm{~cm} \quad \mathrm{x} \quad 25 \mathrm{~cm}$ and HQPM-1 respectively. Half dose of nitrogen and full dose of phosphorus and potassium was applied as basal treatment wise. The sowing was done on $2^{\text {nd }}$ July in both the years of experiment. Pre-harvest and post-harvest i.e. growth and yield components and grain yield were recorded as and when required.

\section{Results and Discussion}

The result of the experiment entitled "Effect of Integrated Nutrient Management on Productivity and Profitability of Maize (Zea mays L.)". The pooled data pertaining to various components used for treatment evaluation were analyzed statistically to test their significance.

\section{Effect of INM on growth components and development of maize}

A perusal of table 1 clearly revealed that growth parameters were significantly influenced by integrated nutrient management. The maximum plant height $(201.90 \mathrm{~cm})$, dry matter accumulation $(213.45 \mathrm{~g})$, number of cobs plant ${ }^{-1}(1.40)$, 
number of grains $\operatorname{cob}^{-1}$ (393.75) and test weight $(223.25 \mathrm{~g})$ was recorded in treatment T3 (150 \% RDF) followed by treatment T5 $\left(\mathrm{RDF}+5\right.$ tons FYM ha $\left.{ }^{-1}\right)$ which recorded plant height, dry matter accumulation, number of cobs plant ${ }^{-1}$, number of grains $\mathrm{cob}^{-1}$ and test weight as $200.30 \mathrm{~cm}, 212.90 \mathrm{~g}, 1.40,391.95$ and $223.15 \mathrm{~g}$ respectively. A critical review of the table also revealed that treatment $T_{5}$ was found to be at par to treatment $T_{3}$ with regards to above mentioned parameters. However, minimum growth parameters was recorded in treatment $\mathrm{T}_{8}$ (Control) followed by treatment $\mathrm{T}_{7}$ (Farmers practice). The probable reason for recording maximum growth attributes may be due to better availability of nutrients in balanced form during vegetative phase (Makinde, 2007 and Rajeshwari et al., (2007).

The other reason might be due to more number of leaves per plant in these treatments which led to more leaf area which is a measure of size of assimilatory system of plant and is a product of leaf length and width which is important for the accumulation and partitioning of photosynthates to the economic parts of the plant.

Table.1 Effect of integrated nutrient management on growth and yield attributes of maize

\begin{tabular}{|c|c|c|c|c|c|}
\hline Treatment & $\begin{array}{c}\text { Plant Height } \\
\text { (cm) }\end{array}$ & $\begin{array}{c}\text { DM/Plant } \\
\text { (g) }\end{array}$ & $\begin{array}{c}\text { No. of } \\
\text { cobs/plant }\end{array}$ & $\begin{array}{c}\text { No. of } \\
\text { grains/cob }\end{array}$ & $\begin{array}{c}\text { Test weight } \\
\text { (g) }\end{array}$ \\
\hline $\mathrm{T}_{1}$ & 187.70 & 166.90 & 1.40 & 358.75 & 213.35 \\
\hline $\mathrm{T}_{2}$ & 194.85 & 208.25 & 1.20 & 378.75 & 216.00 \\
\hline $\mathrm{T}_{3}$ & 201.90 & 213.45 & 1.40 & 393.20 & 223.25 \\
\hline $\mathrm{T}_{4}$ & 190.85 & 196.30 & 1.30 & 358.85 & 214.90 \\
\hline $\mathrm{T}_{5}$ & 200.30 & 212.90 & 1.40 & 391.95 & 223.15 \\
\hline $\mathrm{T}_{6}$ & 196.53 & 202.95 & 1.30 & 382.90 & 216.65 \\
\hline $\mathrm{T}_{7}$ & 180.95 & 163.80 & 1.10 & 339.65 & 206.25 \\
\hline $\mathrm{T}_{8}$ & 170.50 & 143.50 & 0.70 & 323.50 & 203.70 \\
\hline F-test & $\mathbf{S}$ & $\mathbf{S}$ & $\mathbf{S}$ & $\mathbf{S}$ & $\mathbf{S}$ \\
\hline SEm \pm & $\mathbf{7 . 4 9}$ & $\mathbf{6 . 9 4}$ & $\mathbf{0 . 0 9}$ & $\mathbf{4 . 5 6}$ & $\mathbf{1 . 5 4}$ \\
\hline CD(0.05) & $\mathbf{2 2 . 7 1}$ & $\mathbf{2 1 . 0 4}$ & $\mathbf{0 . 2 6}$ & $\mathbf{1 3 . 8 3}$ & $\mathbf{4 . 6 8}$ \\
\hline
\end{tabular}

Table.2 Effect of integrated nutrient management on yield and economics of maize

\begin{tabular}{|c|c|c|c|c|c|}
\hline Treatment & $\begin{array}{c}\text { Grain yield } \\
\left(\mathbf{q ~ h a}^{-\mathbf{1}} \mathbf{)}\right.\end{array}$ & $\begin{array}{c}\text { Stover yield } \\
\left(\mathbf{q} \mathbf{~ h a}^{-\mathbf{1}}\right)\end{array}$ & $\begin{array}{c}\text { Stone yield } \\
\left(\mathbf{q ~ h a}^{-\mathbf{1}} \mathbf{)}\right.\end{array}$ & $\begin{array}{c}\text { Net return } \\
\mathbf{( R s . ~ h a}^{-\mathbf{1})}\end{array}$ & B:C ratio \\
\hline $\mathrm{T}_{1}$ & 48.15 & 127.45 & 12.10 & 32026.00 & 1.30 \\
\hline $\mathrm{T}_{2}$ & 50.10 & 136.05 & 14.05 & 34036.00 & 1.36 \\
\hline $\mathrm{T}_{3}$ & 52.05 & 140.70 & 16.20 & 35914.00 & 1.41 \\
\hline $\mathrm{T}_{4}$ & 47.60 & 132.00 & 12.50 & 32148.00 & 1.32 \\
\hline $\mathrm{T}_{5}$ & 51.70 & 140.10 & 15.50 & 35597.00 & 1.40 \\
\hline $\mathrm{T}_{6}$ & 49.95 & 138.40 & 14.20 & 34159.00 & 1.37 \\
\hline $\mathrm{T}_{7}$ & 23.95 & 95.20 & 10.70 & 9891.00 & 0.51 \\
\hline $\mathrm{T}_{8}$ & 12.10 & 65.60 & 8.60 & 5325.00 & 0.32 \\
\hline F-test & $\mathbf{S}$ & $\mathbf{S}$ & $\mathbf{S}$ & & \\
\hline $\mathbf{S E m} \pm$ & $\mathbf{1 . 3 6}$ & $\mathbf{1 . 1 6}$ & $\mathbf{0 . 7 8}$ & - & - \\
\hline $\mathbf{C D}(\mathbf{0 . 0 5})$ & $\mathbf{4 . 1 2}$ & $\mathbf{3 . 5 1}$ & $\mathbf{2 . 3 6}$ & - & - \\
\hline
\end{tabular}


Fig.1 Effect of integrated nutrient management on yield

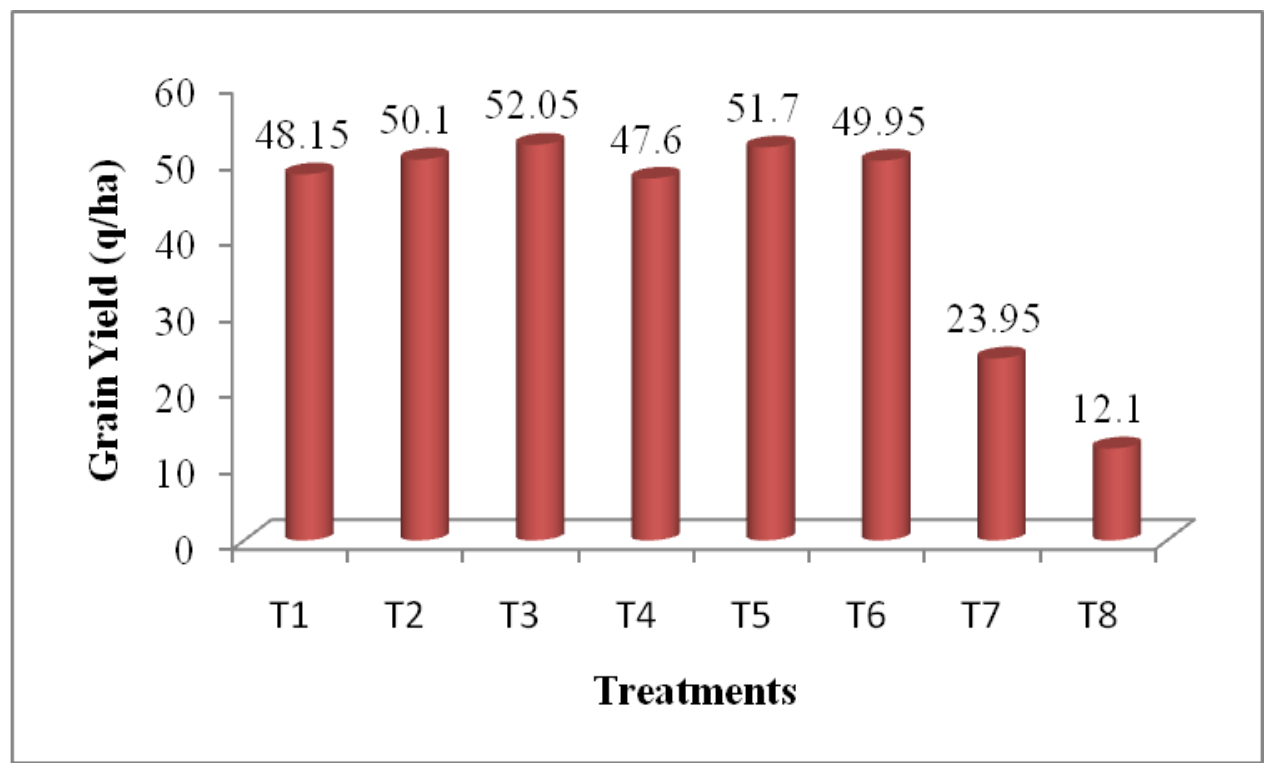

The results so obtained in performances probably due to nutrients were responsible for increased cell division, cell enlargement, growth, photosynthesis and protein synthesis for quantitative increase in plant growth (Panwar, 2008). These findings are in accordance of those reported by Ghafoor and Akthar (1991), Balyan et al., (2006) and Ayoola and Makinde (2009) who stated that application of high doses of nutrients in balanced form has significant effect on growth and development of maize.

\section{Effect of INM on yield of maize}

An appraisal of table 2 and figure 1 clearly revealed that yield parameters were significantly influenced by integrated nutrient management. The maximum grain yield $\left(52.05 \mathrm{q} \mathrm{ha}^{-1}\right)$, stover yield $\left(140.70 \mathrm{q} \mathrm{ha}^{-1}\right)$ and stone yield $\left(16.20 \mathrm{q} \mathrm{ha}^{-1}\right)$ was recorded in treatment $\mathrm{T}_{3}(150 \% \mathrm{RDF})$ followed by treatment $\mathrm{T}_{5}\left(\mathrm{RDF}+5\right.$ tons FYM ha $\left.{ }^{-1}\right)$ which recorded grain yield, stover yield and stone yield as $51.70 \mathrm{q} \mathrm{ha}^{-1}, 140.10 \mathrm{q} \mathrm{ha}^{-1}$ and 15.50 $\mathrm{q} \mathrm{ha}{ }^{-1}$ respectively. A close examine of the table 2 also revealed that treatment $\mathrm{T}_{5}$ was found to be at par to treatment $T_{3}$ with regards to grain yield, stover yield and stone yield while minimum yield was recorded in $\mathrm{T}_{8}$ (Control).Crop yield depends on the accumulation of photos assimilates during the growing period and the way they partitioned between desired storage organs of the plant. In the research carried out during kharif season of 2014 and 2015, grain yield, stover yield and stone yield was significantly influenced by treatment $T_{3}$ and treatment $T_{5}$. The both treatments recorded better yield over rest of the treatments. The probable reason for significant improvement in grain yield was due to superiority of yield attributes viz. Cob weight, grains $\mathrm{cob}^{-1}$ and test weight. The higher growth attributing traits could also be attributed to sustained availability of macro and micro nutrients which may have taken part in nourishment of the crop and also enhanced the activity of meristematic cells and cell elongation where FYM providing micronutrients has favourable effect on metabolic process, enzymatic activity and growth hormones which in turn lead to better vegetative growth in terms of higher plant height and number of leaves eventually contributed to increased dry matter production. These results are in accordance 
with those reported by Shanmugam and Veeraputhran (2000), Iman et al., (2002) and Ranjbar and Bahmaniar (2007).

Economic analysis of maize indicated significantly higher net return (Rs.35914.00) and $B: C$ ratio (1.41) in treatment $T_{3}$ followed by treatment $T_{5}$ which recorded net return and B: C ratio as Rs.35597.00 and 1.40 respectively on account of significantly higher grain, stover and stone yield. Similar findings were also observed by Singh et al., (2005) and Gohawale and Dahipale (2007).

\section{References}

Ayoola, O.T. and Makinde, E.A. 2009. Maize growth, yield and soil nutrient changes with $\mathrm{N}$ enriched organic fertilizers. Afr. J. Food agric. Nutr. Dev. 9: 580-582.

Balyan, J.K., Puspendra Singh, Jain, L.K. and Jat, M.L. 2006. Maize (Zea mays L.) productivity in response to integrated nutrient management in Southern Rajasthan. Curr. Agric., 30(1-2): 63-65

Ghafoor, A. And Akhtar, S.1991. Response of spring maize cv. Agatti-72 to nitrogen fertilization under saline sodic soil culture Pak. J.Agric. Sci. 23: 374-378.

Godhawale, G.V. and Dahipale, R.V. 2007. Production and economic efficiency of rice (Otyza sativa L.) as influenced by nutrition under upland condition. Intl. J. Trop. Agric. 25:209-212.

Iman, A.K., Mohamoud, S.H., Sharanappa and Yayabharath, P. 2002. Effect of composts and fertilizer levels on the structure of growth and yield in maize. Karnataka J. Agric. Sci., 15:22-25

Makinde, E.A. 2007. Effects of an organol mineral fertilization on the growth and yield of maize. J. Applied Sci. Res. 3: 1152-1155.

Panwar A.S.2008. Effect of integrated nutrient management in maize (Zea mays) - mustard (Brassica campestris var. toria) cropping system in mid hills altitude. Indian J. Agricultural Sciences. 78(1):27-31.

Rajeshwari, R.S., Hebsur, N.S., Pradeep, H.M. and Bharamagoudar. 2007. Effect of integrated nutrient management on growth and yield of maize. Karnataka $J$. Agric. Sci. 20: 399-400.

Ranjbar, G.A. and Bahmaniar, M.A. 2007. Effect of soil and foliar application of $\mathrm{Zn}$ fertilizer on yield and growth characteristics of bread wheat (Triticun aestivum L) cultivars. Asian J. Plant Sci. 6: 1000-1005

Shanmugam, P.M. and Veeraputhram, R. 2000. Effect of organic manure, biofertilizer, inorganic nitrogen and zinc on growth and yield of rabi rice (Oryza sativa L.) Madras Agric. J. 88: 514-517.

Singh, B., Kumar, S., Natesan, A., Singh, B.K. and Usha, K. 2005. Improving zinc efficiency of cereal under zinc deficiency. Curr. Sci. 88:36-44.

\section{How to cite this article:}

Shambhu Sharan Kumar, Pradeep Prasad and Daleshwar Rajak. 2017. Effect of Integrated Nutrient Management on Productivity and Profitability of Maize. Int.J.Curr.Microbiol.App.Sci. 6(12): 3878-3882. doi: https://doi.org/10.20546/ijcmas.2017.612.448 